A.A. Shavelkin, J. Gerlici, I.O. Shvedchykova, K. Kravchenko, H.V. Kruhliak

\title{
MANAGEMENT OF POWER CONSUMPTION IN A PHOTOVOLTAIC SYSTEM WITH A STORAGE BATTERY CONNECTED TO THE NETWORK WITH MULTI-ZONE ELECTRICITY PRICING TO SUPPLY THE LOCAL FACILITY OWN NEEDS
}

\begin{abstract}
Purpose. Improving the principles of management of photovoltaic system with storage battery and with autonomous functioning during daylight hours for a local object, connected to the grid with multi-zone payment when excluding the generation of energy into the grid. Methodology. Modeling and analysis of energy processes in the photovoltaic system was performed using the Matlab software package. The simulation model of energy processes is based on calculated expressions taking into account the characteristics of the battery. Operability of the proposed solutions are confirmed on an experimental setup based on a standard hybrid inverter. Results. It's shown, that due to the battery energy during the most loaded peak hours and part of the daytime the system operates autonomously and does not depend on possible violations of the quality of electricity in the grid. Scenarios of the recommended load schedule are proposed in accordance with the ratio of the predicted value of the daily energy generation of the photovoltaic battery to its possible maximum value. A simulation model of energy processes in the system with the correction of the recommended load value was developed. Originality. A method of the recommended load calculation with current correction for the actual generation and degree of battery charge is proposed, which allows taking into account differences the actual generation of the photovoltaic battery from its predicted value and the actual load from the recommended one. Practical value. The obtained solutions are the basis for the design of new and modernization of existing photovoltaic systems of local objects using software and hardware complexes for power consumption management. References 18, figures 4.
\end{abstract}

Key words: multi-zone electricity pricing, energy redistribution, storage battery state of charge, PWM, recommended load scenarios with current correction, simulation.

Удосконалено принципи управління і перерозподілу енергї, яка накопичується в акумуляторній батареї, в фотоелектричній системі локального об'єкта, підключеного до мережі з багатозонною тарифікацією при виключенні генерації енергії в мережу. За рахунок енергії батареї в найбільш навантажені пікові години та частково в денний час система працює автономно $i$ не залежить від можливих спотворень якості електроенергії в мережі. Запропоновано сиенаріі рекомендованого графіка навантаження відповідно до відномення прогнозованого значення денної генерачії енергіі фотоелектричної батареї до ї̈ можливого максимального значення. Запропоновано методику розрахунку рекомендованого навантаження з поточним корегуванням за фактичною генерацією і ступенем заряду батареї, щьо дозволяє врахувати відхилення фактичної генерації фотоелектричної батареї від прогнозного значення $і$ фактичного навантаження від рекомендованого. Розроблено імітаиійну модель енергетичних прочесів в системі з корегуванням значення рекомендованого навантаження. Працездатність запропонованих рімень підтверджено моделюванням в Матlаb $i$ на експериментальній установиі на базі стандартного гібридного інвертора. Отримані рімення є основою для проектування нових і модернізації існуючих фотоелектричних систем локальних об'єктів з використанням програмно-технічних комплексів управління електроспоживанням. Бібл. 18, рис. 4.

Ключові слова: багатозонний тариф, перерозподіл енергї, ступінь заряду акумулятора, ШІМ, сценарії рекомендованого навантаження з поточним корегуванням, моделювання.

Усовершенствованы принципы управления и перераспределения энергии, накапливаемой в аккумуляторной батарее, в фотоэлектрической системе локального объекта, подключенного к сети с многозонной тарификацией при исключении генерации энергии в сеть. За счет энергии батареи в наиболее нагруженные пиковые часы и частично в дневное время система работает автономно и не зависит от возможных нарушений качества электроэнергии в сети. Предложено сценарии рекомендованного графика нагрузки в соответствии с отношением прогнозируемого значения дневной генерации энергии фотоэлектрической батареи к ее возможному максимальному значению. Предложена методика расчета рекомендованной нагрузки с текущей корректировкой по фактической генерации и степени заряда батареи, что позволяет учесть отличия фактической генерачии фотоэлектрической батареи от прогнозного значения и фактической нагрузки от рекомендованной. Разработана имитационная модель энергетических проиессов в системе с корректировкой значения рекомендованной нагрузки. Работоспособность предложенных решений подтверждена моделированием в Маtlab и на экспериментальной установке на базе стандартного гибридного инвертора. Полученные решения являются основой для проектирования новых и модернизации существующих фотоэлектрических систем локальных объектов с использованием программно-технических комплексов управления электропотреблением. Библ. 18, рис. 4.

Ключевые слова: многозонный тариф, перераспределение энергии, степень заряда аккумулятора, ШиМ, сценарии рекомендованной нагрузки с текущей корректировкой, моделирование.

Introduction. «Green» energy and, first of all, photovoltaic systems (PVSs) are becoming more widespread in modern conditions. This also applies to «small» energy, in particular, economic entities - local facilities (LFs) for various purposes. Here, the use of combined (hybrid) PVSs with a storage battery (SB) and connection to a distribution network (DN) allows: to increase the reliability of power supply due to the uninterruptible power supply function in conditions of voltage outages when using solar generation and SB energy; to increase the power consumption of the LF, this is especially important if there is a limit on the power from the power system, when the use of PVSs is cheaper than the construction of a new power transmission line and equipment for connecting to the DN.

(C) A.A. Shavelkin, J. Gerlici, I.O. Shvedchykova, K. Kravchenko, H.V. Kruhliak 
The interest in the sale of electricity at the «green» tariff, along with the provision of their own needs, is not decisive for the LF which is associated with the overestimation of the power of the PVS and with the need for registration of permits. In addition, approaches to «green» tariffs are changing, and the tariffs themselves are decreasing [1]. In this regard, the approach adopted in world practice is promising, when the consumer is a prosumer [2], and energy is consumed where it is generated. This partly alleviates the problems with the management of generation in the power system and the need to ensure the balance of energy.

The effectiveness of the introduction of PVS for business entities is determined in accordance with the increase in production and improved working conditions. At the same time, the introduction of such systems should ensure a reduction in the cost of paying for electricity consumption from the DN, especially taking into account the constant growth of tariffs. It is promising to use a PVS with a SB when connected to DN with multi-zone tariffication with the redistribution of energy between tariff zones [3-5].

The real need for such PVSs is evidenced by the fact that ready-made solutions [6-8] and the development of «hybrid» inverters are widely represented on the electrical market. These solutions represent modern software and hardware complexes: with power supply of the LF from an autonomous voltage inverter (AVI) and switching the LF load to the DN (bypass) with insufficient generation of a photovoltaic battery (PB) and SB energy; with a network inverter (NI), when the load and NI operate in parallel with the DN. These solutions are intended for use in a one-part tariff, have a developed interface with the possibility of remote control of parameters, for example, with output to a smartphone. They have the ability to reconfigure the parameters, but everything is done by the operator, and their effective use requires experience and skills. There are no functions for generating recommendations and automatic adjustment according to the weather forecast.

The cycle of operation of hybrid inverters provides for the power supply of the LF load from the PB with recharging the $\mathrm{SB}$; if the $\mathrm{PB}$ energy is insufficient, the $\mathrm{SB}$ energy is used. When the state of charge of the SB drops to the threshold value, the transition to the bypass mode is carried out, and the LF load is connected to the DN with the SB charge (from the $\mathrm{PB}$ and the $\mathrm{DN}$ ); if the SB energy is sufficient, the LF is powered again from the SB. The improvement of PVS in the conditions of multi-zone tariffication is associated with the binding of switching of operating modes to the hours of tariff zones, control of the energy supply from the PB and the SB charge. Here, it becomes possible to exclude energy consumption during peak loads $[4,5]$, the discharge of the SB charged from the night (according to the night rate) in the morning hours until the morning peak is excluded, and the SB is charged until the evening peak.

In real conditions, when using worn out and overloaded DNs, the option with AVI has an advantage, which, if energy consumption is excluded from the DN during peak loads and during light time, ensures the autonomous operation of the LF. In this case, the quality of the LF voltage is determined by the AVI, which will contribute to the normal functioning of the LF in the event of deterioration in the quality of the DN voltage. When using a NI operating in parallel with a DN, switching to stand-alone mode can be accomplished by disconnecting from the DN.

In solutions of PVS with hybrid inverters, the use of a SB is considered, the energy consumption of which $W_{B}$ varies within wide limits $-W_{B}=1-4.8 \mathrm{~kW} \cdot \mathrm{h}$ for a PB with power of $P_{r}=1 \mathrm{~kW}$. Obviously, the $W_{B}$ value is determined by the system functioning algorithm. At the same time, the cost of the SB is significant and requires justification from the condition of sufficiency.

The use of daily meteorological forecast looks promising with the formation of recommendations on the LF load schedule $P_{L}(t)$ which will allow planning operation modes and ensuring a reduction in energy consumption from the DN at more expensive tariffs. It becomes possible to automatically adjust according to the season and forecast. Various approaches are used using data from meteorological sites [9]. An interesting and modern solution is forecasting using neural networks $[10,11]$. At the same time, the availability of the most accurate forecast does not solve the issue of efficient use of the energy of the PB and SB without linking $P_{L}(t)$ to it. And here it seems appropriate to use the system with the formation of the $P_{L R}(t)$ load schedule recommended in accordance with the forecast under various operating scenarios. Since it is impossible to ensure an exact match of the $P_{L R}(t)$ load, it is advisable to use the current $P_{L R}(t)$ correction. The correction can be carried out according to the actual parameters of the PVS. This issue requires further study. In this case, the forecast accuracy of the PB generation $P_{P V}(t)$ at the level of the meteorological site data can be sufficient for effective correction [12].

Simulation modelling is an effective tool for studying the possibilities of controlling energy processes in PVS [13-15]. Here, the introduction of additional elements makes it possible to assess the possibilities and efficiency of correcting the $P_{L R}(t)$ load schedule for various deviations of the actual $P_{P V F}(t)$ and the predicted $P_{P V P}(t)$ generation of the PB.

The goal of the work is to improve the management principles for a photovoltaic system with a storage battery and autonomous operation during the daytime for a local facility connected to a multi-zone billing network while excluding the generation of energy to the network.

It is necessary to solve the following tasks:

- to study the possibility of using a limited number of scenarios of operation with the recommended load schedule based on the forecast of the PB generation with the current correction based on the actual values of generation and the degree of SB charge;

- to develop a simulation model of the system to study energy processes in the daily cycle using the recommended load correction;

- to carry out experimental validation using a standard hybrid inverter.

The structure of the power circuits of the PVS. The structure of a PVS with a SB (using the example of a single-phase version of the PVS implementation, see 
Fig. 1) is based on a standard approach and contains: an autonomous inverter (VSI) with an output LC filter, PB (PV), SB, Load, DN (G) and switching devices. The PB is connected to the AVI input through a DC/DC1 step-up converter with the Maximum Power Point Tracking (MPPT) function, the SB is connected through a DC/DC2 (charge controller) with two-way conduction. As a starting point, a variant with the use of a hybrid inverter of the Axioma Energy ISMPPT 3000 type $(3 \mathrm{kVA})$ is considered. The LF load is connected to the AVI output and through the $\mathrm{K} 1$ contactor with the VS triac - to the DN. The AVI with PWM and an output filter is used as a source of sinusoidal voltage, and when the load is connected to the network, it is used in the SB charging mode. $\mathrm{K} 1$ is needed to disconnect the PVS from the DN when the voltage disappears in it (emergency mode). VS is used to exclude a pause when connecting to the DN when the voltage is restored in it (first, $\mathrm{K} 1$ is closed, and after synchronizing the AVI voltage $u_{C}$ with the network voltage $u_{g}$, the triac is switched on). Relay K2 is used to switching off the PB. Voltage and current sensors in Fig. 1 are not shown.

Let us consider the operation of the PVS in a daily cycle with autonomous operation when the energy of the $\mathrm{PB}$ and the SB is sufficient to consume the LF load and switching to bypass when the energy of the PB and SB is insufficient. A variant of the load graph $P_{L}(t)$ is shown in Fig. 2 (bypass zones are highlighted). The following conventional zones and relative tariffs have been adopted: daytime $T_{d}=1 \quad\left(t_{2}=11: 00-t_{5}=20: 00\right)$, nighttime $T_{n}=0.4$ $\left(t_{6}=22: 00-t_{1}=7: 00\right)$, peak morning $T_{m}=1.5\left(t_{1}=7: 00-\right.$ $\left.t_{2}=11: 00\right)$ and evening $T_{e}=1.5\left(t_{5}=20: 00-t_{6}=22: 00\right)$. In this case, an unfavorable option is considered, when the peak loads are shifted by the hours of minimum PB generation.

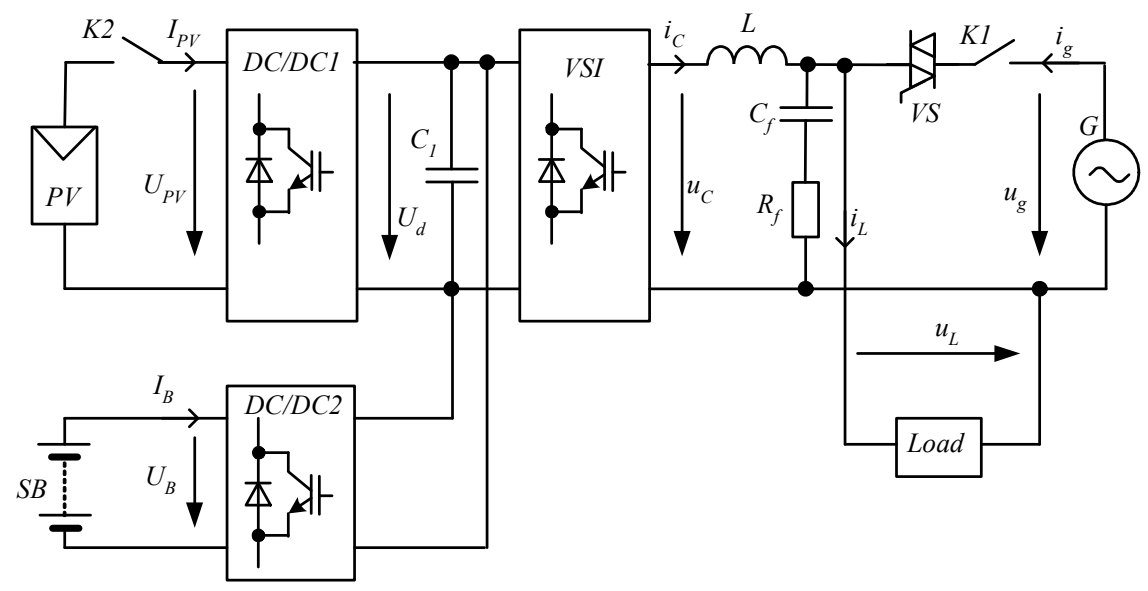

Fig. 1. Structure of the power circuits of the PVS

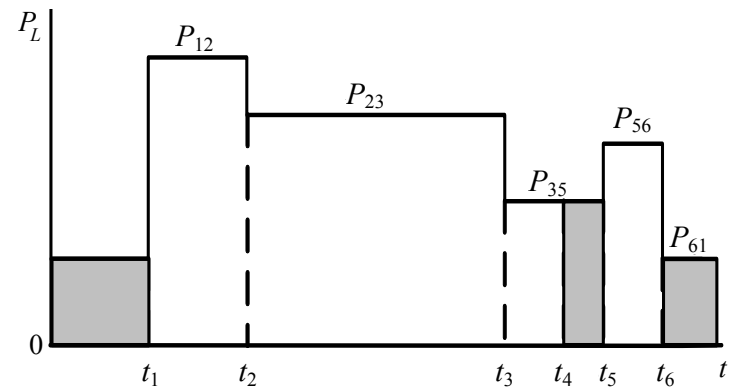

Fig. 2. Dependence $P_{L}(t)$

In this case, it is necessary to take into account the peculiarities of the charging characteristics of the SB. The standard solution uses a charge in three stages [16, 17]. In this case, the «active» is the first stage when the state of charge (SOC) of the SB $Q^{*}=100 \cdot Q / Q_{r} \leq 80 \%(Q$ and $Q_{r}$ are the current and nominal values, respectively), when the charge current $I_{B}$ for different $\mathrm{SB}$ types can vary from 0 to $I_{B \max }=(2 \div 3) I_{B r}=(0.2 \div 0.3) C_{B}\left(C_{B}\right.$ is the $\mathrm{SB}$ capacitance, $I_{B r}=0.1 C_{B}$ is the nominal value). With further charging, the current decreases significantly and, accordingly, the ability of the SB to receive energy decreases.

The depth of discharge (DOD) and the number of discharge cycles $n_{r c}$ determine the SB life. Usually the acceptable DOD does not exceed 30-50 \%. Thus, DOD must be controlled, limited (not lower than $50 \%$ ), and SOC must be maintained in the active zone, for example, $75-80 \%$. This is possible with the use of a relay regulator acting on relay $\mathrm{K} 2$ (Fig. 1) with $\mathrm{PB}$ disconnection. This applies to the time interval when $P_{P V}>P_{L}$ and it is possible to charge the SB using the energy of the PB. In the early evening, when $P_{P V} \leq P_{L}$, when $Q^{*}$ drops to the set value $Q^{*}$, the load and the inverter are connected to the DN with the SB charge from the PB and the network.

The autonomous operation of the PVS with limited SB capacitance also imposes an additional limitation - the need to reduce the generation of the SB when its energy is excessive and there is nowhere to put it.

We proceed from the data on the generation of the PB $P_{P V}(t)$ in the conditions of Kyiv according to the archival data [18]. As an indicator of the efficiency of PVS, we use a simplified indicator $k_{E}=C_{1} / C_{2}\left(C_{1}\right.$ and $C_{2}$ are the cost of electricity consumed by the LF and the cost of electricity consumed from the DN). Let us consider various options for LF load schedules with constant generation $P_{P V}(t)$ and with a change in the SB capacitance. Energy $W_{B f}$, given by the $\mathrm{SB}$, taking into account the efficiency $\eta_{B}$ of the SB and the efficiency $\eta_{C}$ of the converter is $W_{B f}=W_{B} \eta_{B} \eta_{C}\left(W_{B}=U_{B} C_{B}, U_{B}\right.$ is the $\mathrm{SB}$ voltage). We accept $W_{B f}$ values from $1 \mathrm{~kW} \cdot \mathrm{h}$ to $4.8 \mathrm{~kW} \cdot \mathrm{h}$. We are considering the option of using lead- 
acid SBs of the OPzV12-100 type (12 V, $100 \mathrm{Ah}$ ), which at DOD up to $50 \%$ provide for at least 2500 discharge cycles. With a two-hour discharge at $U_{B}=1.85 \mathrm{~V}$, $I_{B}=29.5 \mathrm{~A}$, the discharge power is $57.6 \mathrm{~W}$, and, accordingly, $\eta_{B}=0.947$ [17]. In this case, the SB is used in the active charging zone up to $Q^{*}=80 \%$, and only in the hours preceding the peak hours, it is possible to charge the SB from the network over $80 \%$.

Mode of operation with constant load from 7:00 to 20:00. In the evening, with a decrease in $P B$ generation, connection to the $\mathrm{DN}$ is inevitable at time $t_{4}$. We accept the control values $Q^{*}=95 \%, Q_{5}=85 \%$, $Q^{*}=62 \%, Q^{*}{ }_{\min } \geq 50 \%$. In accordance with [17], the duration of the SB charge from $Q^{*}=62 \%$ to $Q^{*}{ }_{5}=83-85 \%$ is approximately $\Delta t=2.5$ hours, respectively, $t_{4}=17: 30$.

In the hours of the evening peak $\left(t_{5}, t_{6}\right)$ at $\Delta Q^{*}{ }_{56}=$ $=Q^{*}{ }_{5}-Q^{*}{ }_{\text {min }}$, the value of the load power $P_{56}$ can be taken from the condition of providing a two-hour discharge $\left(t_{56}=2 \mathrm{~h}\right)$

$$
P_{56}=\frac{\Delta Q *{ }_{56} W_{B f}}{\left(t_{6}-t_{5}\right) 100} \text {. }
$$

For the interval $\left(t_{1}, t_{4}\right) \Delta Q *{ }_{14}=Q^{*}{ }_{1}-Q^{*}, W_{P V 14}$ is the energy generated by the $\mathrm{PB}$ on the interval $\left(t_{1}, t_{4}\right)$ in accordance with $P_{P V}(t)$, and the load power $P_{\mathrm{L}}=P_{14}=P_{15}$

$$
\begin{aligned}
& W_{B 14}=\frac{\Delta Q^{*}{ }_{14} W_{B f}}{\left(t_{4}-t_{1}\right) 100}, \\
& P_{14}=\frac{W_{B 14}+W_{P V 14} \eta_{C}}{t_{4}-t_{1}} .
\end{aligned}
$$

To exclude a deep discharge of the SB $\left(Q_{2}^{*} \geq 62 \%\right)$ during the morning peak hours $\left(t_{1}, t_{2}\right)$, a similar calculation is performed for $P_{12}$. The lower power value is taken as $P_{L}$.

When charging the SB from the network, energy is consumed:

- on the interval $\left(t_{6}, t_{1}\right)-W_{B C}=0.01 \Delta Q^{*}{ }_{61} W_{B f}$

- on the interval $\left(t_{4}, t_{5}\right)-W_{B C 45}=0.01 \Delta Q^{*}{ }_{45} W_{B f}$.

Part of the SB energy is compensated by the energy $W_{P V 45}^{l}$ generated by the $\mathrm{PB}$ at this time $W_{P V 45}^{l}=W_{P V 45} \eta_{B} \eta_{C}$ (by $t_{1}$ the $\mathrm{SB}$ is practically charged, and the PB energy is not used).

We accept the LF night load $P_{L N}=P_{14} / 3$. Then $k_{E}=\frac{0.4\left(t_{6}-t_{1}\right) P_{L N}+1.5\left[P_{L}\left(t_{2}-t_{1}\right)+P_{56}\left(t_{6}-t_{5}\right)\right]+P_{L}\left(t_{5}-t_{2}\right)}{0.4\left(t_{6}-t_{1}\right) P_{L N}+0.4 W_{B C}+1.0 W_{B C 45}+P_{L}\left(t_{5}-t_{4}\right)-W_{P V 45}^{1}}$.

The values of the index $k_{E}$ at $W_{P V C}=$ const $\left(W_{P V C}\right.$ is the total energy generated by the $\mathrm{PB}$ ) decrease with increasing $W_{B}$. For example, with $W_{B}=1828 \mathrm{~W} \cdot \mathrm{h}-$ $k_{E}=3.45$, with an increase in capacitance by 1.5 times $\left(W_{B}=2742 \mathrm{~W} \cdot \mathrm{h}\right)-k_{E}=3.4$, with an increase in capacitance by 2 times $\left(W_{B}=3656 \mathrm{~W} \cdot \mathrm{h}\right)-k_{E}=3.17$. When $W_{B}=2742 \mathrm{~W} \cdot \mathrm{h}$ values $Q^{*}{ }_{2}=Q^{*}{ }_{4}$ i.e. there is a balance between the energy generated by the $\mathrm{PB}$ and the consumed by the load. With a smaller SB capacitance, the values $Q^{*}<Q^{*}$, and there is an excess of PB energy after 11:00, which leads to a SB charge $Q^{*} \geq 80 \%$ and the need to regulate the energy supply from the $\mathrm{PB}$, i.e. the energy of the PB is underused. With a larger SB capacitance, the situation is reversed and $Q{ }^{*}<{ }_{4} *_{2}$. With close values of $k_{E}$ for $W_{B}=1828 \mathrm{~W} \cdot \mathrm{h}$ and $W_{B}=2742 \mathrm{~W} \cdot \mathrm{h}$, it should be borne in mind that at $W_{B}=1828 \mathrm{~W} \cdot \mathrm{h}$, the value of the load power $P_{12} \approx P_{A V D}\left(P_{A V D}\right.$ is the average value of the $\mathrm{PB}$ generation power per day), and in the evening peak $P_{56}$ is almost half as low. At $W_{B}=2742 \mathrm{~W} \cdot \mathrm{h}$, the value of $P_{56}$ is close to $P_{A V D}$, and $P_{12}$ exceeds $P_{A V D}$, i.e. this value of the $\mathrm{SB}$ capacitance is preferable.

The solar activity time for the summer period is limited to $t_{3}=16: 30$ and the $k_{E}$ value can be increased (up to $\left.k_{E}=(4.1-4.6)\right)$ with a decrease in $P_{L}$ in the interval $\left(t_{3}, t_{5}\right)$. Here, $P_{13}$ increases. However, the capacity of the $\mathrm{SB}$ is underused during the morning peak hours.

Let us consider the option $P_{L}(t)$ (Fig. 2) while ensuring the maximum value of $P_{12}$ and reducing the load $P_{35}$. This will reduce the bypass time to 1.5 hours $\left(t_{4}=18: 30\right)$, which is enough to charge the SB by $10 \%$. We assume that $Q *_{1}=95 \%, Q *_{2}=55 \%, Q_{3}=78 \%$ (less than $80 \%), Q^{*}=75 \%, Q{ }_{5}=85 \%$.

The values of $W_{B 12}, W_{B 23}, W_{B 34}$ are determined in accordance with (2), $P_{12}, P_{23}, P_{34}=P_{45}-$ in accordance with (3), $P_{56}-$ in accordance with (1). Then

$k_{E}=\frac{0.4\left(t_{6}-t_{1}\right) P_{L N}+1.5\left[P_{12}\left(t_{2}-t_{1}\right)+P_{56}\left(t_{6}-t_{5}\right)\right]+P_{23}\left(t_{3}-t_{2}\right)+P_{34}\left(t_{5}-t_{3}\right)}{0.4\left(t_{6}-t_{1}\right) P_{L N}+0.4 W_{B C}+W_{B C 45}+P_{45}\left(t_{5}-t_{4}\right)-W^{1} P V 45}$.

According to the calculation results, we have the same situation with respect to $k_{E}$ at different values of the SB capacitance: $W_{B}=1828,2742,3656 \mathrm{~kW} \cdot \mathrm{h}$, when $k_{E}=5.47,5.15,4.73$. Based on the possibility of providing close to $P_{A V D}$ values of $P_{23}$ and $P_{56}$ with an increase in $P_{12}$, it is preferable to use a SB with $W_{B}=2742 \mathrm{~kW} \cdot \mathrm{h}$. Also, the SB must be able to accept the energy of the PB. Typically allowable charging current is $I_{B} \leq(0.2 \div 0.3) C_{B}$. The maximum value of the $\mathrm{PB}$ power for a clear day in June [18] is $P_{P V \max }=0.76 P_{P V}$. The SB with $W_{B}=2742 \mathrm{~W} \cdot \mathrm{h}$ is capable of accepting the excess energy of the $\mathrm{PB}$ at $P_{L} \geq 0.42 P_{P V A D}$ and current $I_{B}=0.2 C_{B}$, and at $I_{B}=0.277 C_{B}-$ even at $P_{L}=0$. Thus, $P_{P V}: W_{B}=1: 2.74$ is accepted.

Solar generation depends on the season of the year and weather conditions, and the recommended load also needs to be changed. At the first stage of development, three $P_{L R}(t)$ scenarios were considered, which are determined by the ratio $w=W_{P V P} / W_{P V \max }\left(W_{P V P}\right.$ is the energy generated by the PB for the current day according to the forecast, $W_{P V \max }$ is the maximum value of the $\mathrm{PB}$ generation according to statistical data on a clear summer day). With $\mathrm{PB}$ power of $1 \mathrm{~kW}$ in the conditions of Kyiv [18], according to $W_{P V \max }$, the average power value per 24 hours is $P_{P V C} \approx 250$, for a day $P_{A V D}=500 \mathrm{~W}$. If $w \geq 0.7$, the load scenario CS1 is selected, if $0.7>w \geq 0.4-\mathrm{CS} 2$, if $0.4>w-\mathrm{CS} 3$.

The CS1 scenario is focused on the maximum use of the energy of the PB and the SB during peak hours and in the daytime (Fig. 2), the calculation of power values is discussed above.

The goal of the CS2 scenario is to increase the average load power during the day, with a certain increase in the duration of the bypass in the evening from 17:30 $\left(t_{4}\right)$ to 20:00. In this case, we have three stages of load change: $\left(t_{1}, t_{3}=16.30\right),\left(t_{3}, t_{5}\right),\left(t_{5}, t_{6}\right)$. We take the value $P_{35}=0.7 P_{13}, Q_{4}=62 \%, Q^{*}=95 \%$. The energy consumed in the interval $\left(t_{1}, t_{4}\right)$ by the load is $W_{L 14}=P_{13}\left(t_{3}-\right.$ $\left.-t_{1}\right)+0.7 P_{13}\left(t_{4}-t_{3}\right)=P_{13}\left[\left(t_{3}-t_{1}\right)+0.7\left(t_{4}-t_{3}\right)\right]$. The value 
$W_{L 14}=\eta_{C} \cdot W_{P V 14}+W_{B 14}$. The value of $P_{12}$ is also determined from the condition $\Delta Q{ }^{*}{ }_{12} \leq 40 \%$. Accordingly, the condition $P_{13} \leq P_{12}$ must be satisfied. The $P_{56}$ value is determined by (1). Thus, until 17:30,1/3 of the SB energy $\left(\Delta Q^{*}{ }_{14}=33 \%\right)$ is used, which is added to the PB energy, which, at $w=0.7$, allows providing an average value of the load power at the level of $0.8 P_{A V D}$, at $w=0.4-$ at the level of $0.5 P_{A V D}$.

In the CS3 scenario, bypass prevails, and it is realistic to exclude energy consumption from the DN during peak hours due to the SB power. Load schedule is similar to $\mathrm{CS} 2$. It makes no sense to take $P_{L R}$ by calculation, since this value is small. Therefore, the value of $P_{12}$ is taken at the level of $P_{12}=0.5 P_{A V D}$ with a conscious increase in the cost of paying for electricity. Also, in the daytime, a restriction of $Q^{*} \geq 60 \%$ is introduced, since in the event of an emergency shutdown of the DN with low PB generation, it is possible to remain without electricity at night. The $P_{56}$ value is determined by (1). On a clear winter day at $w \approx 0.3$ in the midday hours, $P_{P V}$ exceeds the value of $P_{A V D}$, therefore, the PVS operates autonomously at this time.

The basis for the formation of the recommended load schedule is the meteorological forecast, which can change during the day, the predicted values of $P_{P V P}$ differ from the actual generation $P_{P V F}$. The values that the actual LF load can take have a certain discreteness and cannot exactly correspond to the recommendations; the peculiarities of the LF functioning should also be taken into account. Thus, there is a need for current adjustment of the recommendations, which is possible based on the values of $P_{P V P}$ and $P_{P V F}$, as well as the actual degree of charge in $Q_{F}^{*}$.

The averaged value of $P_{P V F i}$ is used in the 5-10 min interval preceding the time $t_{i}$ when the correction is made. The value $p_{i}=P_{P V F i} / P_{P V P i}\left(P_{P V P i}\right.$ is the value at the moment $\left.t_{i}\right)$ is determined. The value of the $\mathrm{PB}$ energy at the corresponding stage $P_{L R}(t)$, starting from $t_{i}$, is taken equal to $W_{P V i}=p_{i} W_{P V P i}\left(W_{P V P i}\right.$ is the predicted value). The $P_{L R}(t)$ value is recalculated according to the expressions (1)-(3) corresponding to the current stage of the schedule. At the next correction point $t_{i+1}$, the procedure is similar.

To test the effectiveness of this method, a simulation model of energy processes in a PVS was developed using a Correction Load Unit (CLU). Here, it is possible to adjust the LF load in a step-by-step mode with the use of a programmable pause and subsequent continuation of the simulation. The correction step is $0.5 \mathrm{~h}$. The CLU includes a set of sampling-storage devices with a $0.5 \mathrm{~h}$ step for measuring the values of $P_{P V F}, P_{P V P}, Q_{F}^{*} \operatorname{PLR}(t)$ is calculated using expressions corresponding to the selected scenario.

$W_{P V P}$ values for the time intervals corresponding to the correction points 7:00, 7:30,.. 20:00 (for example, for point $7: 30$ in the CS1 scenario this is the interval $(7: 30-11: 00))$, the duration of the intervals (in this case, $t_{2}-t_{i}=3.5 \mathrm{~h}$ ), as well as the control values $Q^{*}$ by intervals (in this case $Q{ }^{*} C_{C}=Q{ }_{2}=55 \%$ ) are set in tabular form. Also, the dependencies $P_{P V P}(t)$ are set in tabular form (according to archival data [18] for Kyiv city at $P_{P V r}=1 \mathrm{~kW}$ ),
$P_{P V F}(t)$ and $P_{L R 1}(t)$ is the recommended load schedule according to the forecast at the moment $t_{1}=7: 00$. The $P_{L}$ correction is carried out directly in the $P_{L R I}(t)$ table. The $k_{E}$ value per $24 \mathrm{~h}$ is also calculated.

The SB model is made according to the catalog data. SB charge taking into account energy losses $Q=Q_{S}+\int I^{1} B \cdot d t$, where $Q_{S}$ is the initial value, $I_{B}^{1}=I_{B} \eta_{B}-$ when charging and $I_{B}^{1}=I_{B} / \eta_{B}$ - when discharging the SB. The $I_{B}$ value is formed in accordance with the SB charging characteristics [17] in the form of $I_{B}\left(Q^{*}\right)$. In the discharge mode, a limitation of the permissible value of $I_{B r c \max }$ was introduced for $30 \mathrm{~min}$. This is implemented using an adjustable limit, when the upper limit is set as $I_{B}\left(Q^{*}\right)$, and the lower limit is $I_{B r c \max }$. The SB voltage is also set as the $U_{B}\left(Q^{*}\right)$ dependence. $I_{B}$ value in the stand-alone mode

$$
I_{B}=\frac{K_{2} P_{P V} \cdot \eta_{C}-P_{L}}{U_{B}},
$$

where $K_{2}$ is the relay stay $\left(K_{2}=1\right.$, when the relay is on, and $K_{2}=0$, when the relay is off).

Since $Q^{*} \leq 80 \%$ is maintained in stand-alone mode, there is no current $I_{B}$ limitation.

When connected to the network (bypass)

$$
I_{B}=\frac{P_{P V} \cdot \eta_{C}+P_{g a} \cdot \eta_{C}}{U_{B}},
$$

where $P_{g a}$ is the power consumed from the network when $P_{P V}$ is not enough to provide SB charging at the specified current value, subject to the limitation specified as $I_{B}\left(Q^{*}\right)$.

The $K_{2}$ value is set by the relay element, which switches to the state: $K_{2}=0$ at $P_{P V} \cdot \eta_{C} \geq P_{L}$ and condition $Q^{*} \geq 80 \% ; K_{2}=1$ at $P_{P V} \cdot \eta_{C}<P_{L}$ and condition $Q^{*} \leq 75 \%$. The load is connected to the network provided that 20:00 $\geq t \geq 12: 00, P_{P V} \cdot \eta_{C}<P_{L}, Q^{*} \leq Q^{*}$, and also regardless of other factors at $Q^{*} \leq 50 \%$.

Simulation results in Matlab. The use of correction on the interval $\left(t_{1}, t_{3}\right)$ is considered. Under ideal conditions for a clear day in June $\left(P_{P V F}(t)=P_{P V P}(t)\right)$ and load $P_{L R I}(t)$, the value $k_{E}=5.63$. With a slight discrepancy between the values of $P_{P V F}(t)$ and $P_{P V P}(t)$ at separate time intervals (Fig. 3) and $P_{L R 1}(t)$, the value $k_{E}=4.91$. In the case of load power correction (Fig. 3) $k_{E}=5.302$.

At the value $P_{P V F}(t)=0.9 P_{P V P}(t)$ and $P_{L R 1}(t) k_{E}=4.01$. When using correction (Fig. 4) $k_{E}=5.098$. In the case when the actual generation is higher $P_{P V F}(t)>P_{P V P}(t)$, there is no special need for correction, since $k_{E}$ increases, with $P_{P V F}(t)=1.15 P_{P V P}(t)$ the value $k_{E}=5.735$. When using correction $k_{E}=6.206$.

At present, an experimental setup has been manufactured on the basis of the Axioma Energy ISMPPT 3000 hybrid inverter (with a built-in MPPT controller for connecting a $\mathrm{PB}$ and a $\mathrm{SB}$ charge controller) with a developed software module for power consumption control. The first tests with $\mathrm{PB}$ in $\mathrm{CS} 3$ conditions (according to weather conditions of early December) were carried out, which are planned to be continued (without waiting for summer) on an experimental setup using an electronic PB emulator. 


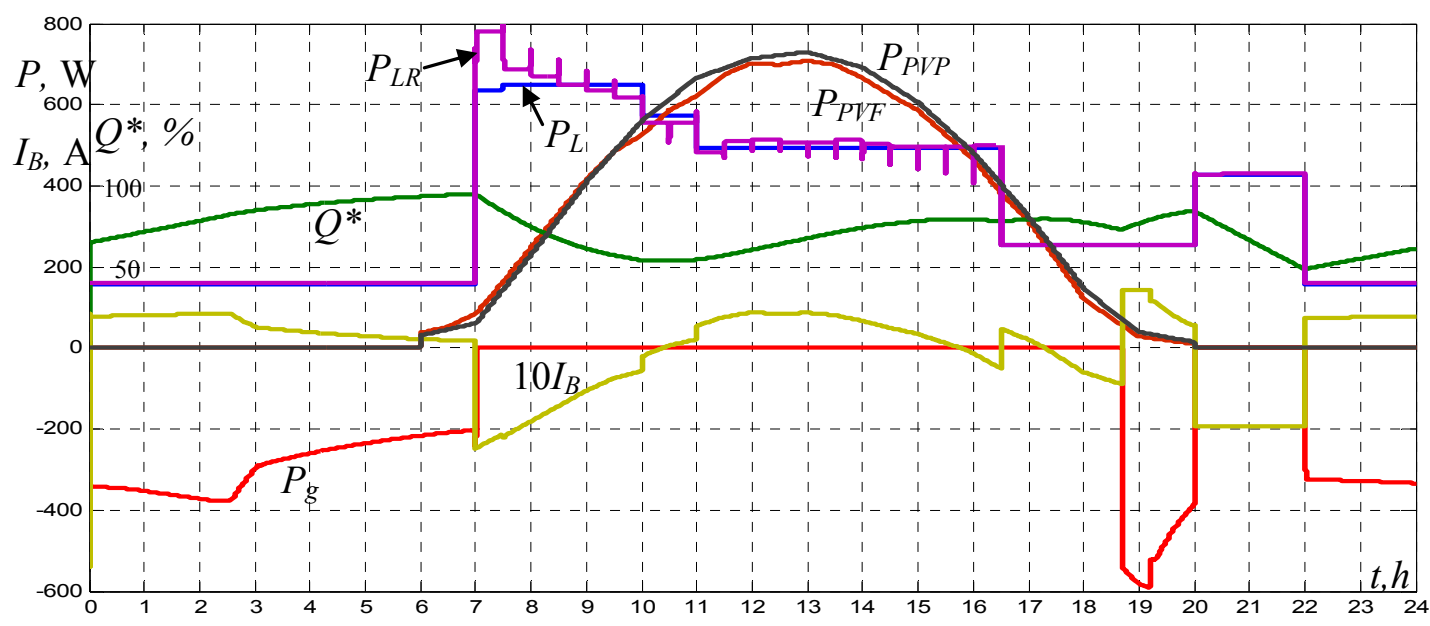

Fig. 3. Oscillograms of the $24 \mathrm{~h}$ cycle of the PVS operation

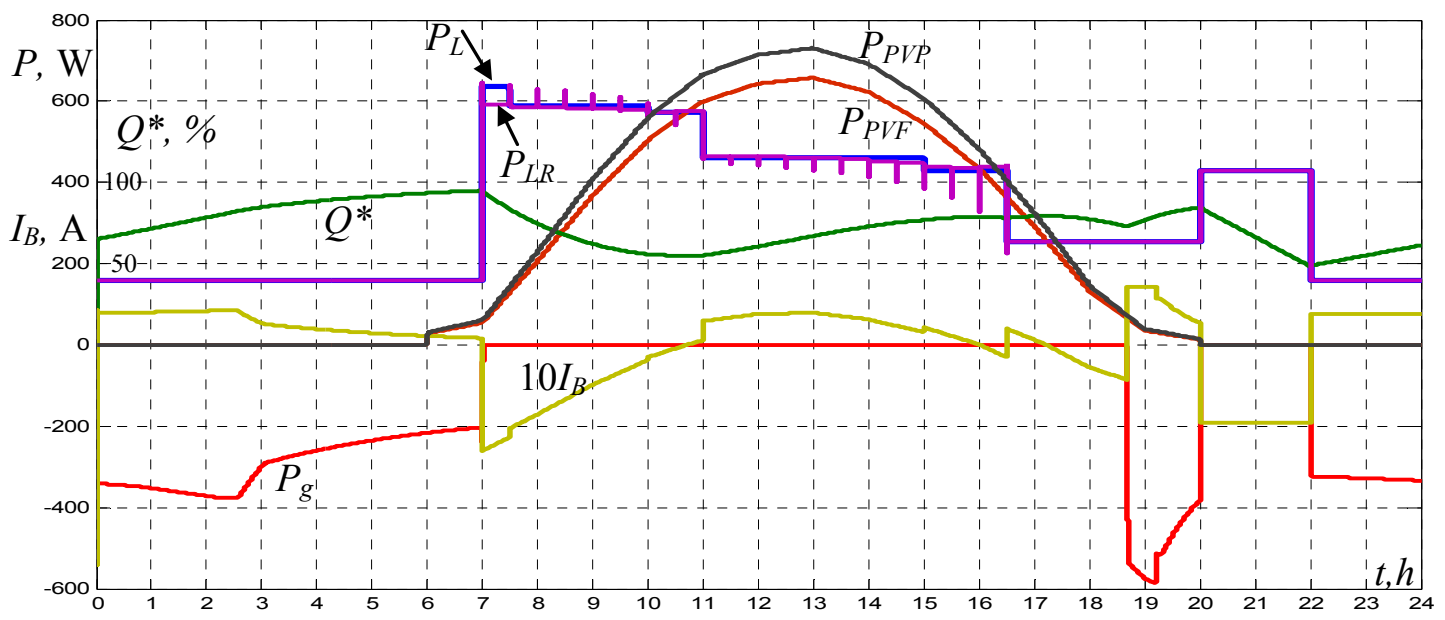

Fig. 4. Oscillograms of the $24 \mathrm{~h}$ cycle of the PVS operation at $P_{P V F}(t)=0.9 P_{P V P}(t)$

Conclusions. The key to ensuring the efficiency of PVS is the use of software and hardware complexes that provide power consumption control, as well as recommendation functions with their correction. In this case, the subject-consumer is provided with information that allows organizing energy consumption for the day ahead while reducing the cost of paying for electricity. In the absence of a response to the recommendations, the system remains operational, eliminating the SB discharge below the set level. The approaches discussed in the article can be also used with a different schedule of tariff zones during peak hours.

The proposed solutions can be used in the development of new and modernization of existing PVS with hybrid inverters when connected to a network with multi-zone tariffication. The considered solution does not imply parallel operation of the inverter with the DN. This limits the possibilities of its application, since the load power depends on solar generation. Therefore, the further development of the work is to improve the principles of PVS implementation using a network inverter, when the load is supplied from the AVI and DN.

Conflict of interest. The authors declare that they have no conflicts of interest.

\section{REFERENCES}

1. Pro vnesennia zmin do deiakykh zakoniv Ukrainy shchodo udoskonalennia umov pidtrymky vyrobnytstva elektrychnoi enerhii z alternatyvnykh dzherel enerhii: Zakon Ukrainy vid 21 lypnia 2020 r. № 810-IX [On amendments to some laws of Ukraine regarding the improvement of conditions for supporting the production of electrical energy from alternative energy sources: Law of Ukraine of July 21, 2020 No. 810-IX]. Available at: https://zakon.rada.gov.ua/laws/show/810-20\#Text (Accessed 15.08.2020). (Ukr).

2. Rao B.H., Selvan M.P. Prosumer participation in a transactive energy marketplace: a game-theoretic approach. 2020 IEEE International Power and Renewable Energy Conference, Karunagappally, India, 2020, pp. 1-6. doi: https://doi.org/10.1109/iprecon49514.2020.9315274.

3. Moira L. Nicolson, Michael J. Fell, Gesche M. Huebner. Consumer demand for time of use electricity tariffs: A systematized review of the empirical evidence. Renewable and Sustainable Energy Reviews, December 2018, vol. 97, pp. 276289. doi: https://doi.org/10.1016/j.rser.2018.08.040.

4. Shavelkin A., Shvedchykova I. Management of generation and redistribution electric power in grid-tied photovoltaic system of local object. Technical electrodynamics, 2020, no. 4, pp. 55-59. doi: https://doi.org/10.15407/techned2020.04.055.

5. El-Hendawi M., Gabbar H.A., El-Saady G., Ibrahim E.-N. A. Optimal operation and battery management in a gridconnected microgrid. Journal of International Council on Electrical Engineering, 2018, vol. 8, no. 1, 195-206. doi: https://doi.org/10.1080/22348972.2018.1528662.

6. Hybrid Grid Inverter Growatt Hybrid 10000 HY. Available at: $\quad$ https://alfa.solar/ru/gibridnyj-setevoj-invertor-growatthybrid-10000-hy-id494.html (Accessed 15.08.2020). (Rus). 
7. Conext SW. Hybrid Inverter. Available at: https://www.se.com/ww/en/product-range-presentation/61645conext-sw/ (Accessed 15.08.2020).

8. ABB solar inverters. Product manual REACT-3.6/4.6-TL (from 3.6 to $4.6 \mathrm{~kW}$ ). Available at: https://www.X-win.it/wpcontent/uploads/2017/03/REACT-3.6 4.6-TL-Product-manualEN-RevBM0000025BG.pdf (Accessed 15.08.2020).

9. Shvedchykova I.O., Kravchenko O.P., Romanchenko J.A., Kozakov E.V. Development of a database for predicting the solar generation in the software and technical complex for the management of electrical supply of the local object. Scientific papers of Donetsk National Technical University. Series: Electrical and Power Engineering, 2020, no. 1 (22), pp. 55-61. (Ukr). doi: https://doi.org/10.31474/2074-2630-2020-1-55-61.

10. Kaplun V., Shtepa V., Makarevych S. Neuro-network model for providing electricity generation by renewable sources in energy management system of local object. Power Engineering: Economics, Technique, Ecology, 2019, no. 2, pp. 27-39. (Ukr) doi: https://doi.org/10.20535/1813-5420.2.2019.190002.

11. Naderipour A., Abdul-Malek Z., Zahedi Vahid M., Mirzaei Seifabad Z., Hajivand M., Arabi-Nowdeh S. Optimal, Reliable and Cost-Effective Framework of Photovoltaic-Wind-Battery Energy System Design Considering Outage Concept Using Grey Wolf Optimizer Algorithm - Case Study for Iran. IEEE Access, 2019, vol. 7, pp. 182611-182623. doi: https://doi.org/10.1109/access.2019.2958964.

12. Forecast. Solar. Available at: https://forecast.solar/ (Accessed 15.08.2020).

13. Traore A., Taylor A., Zohdy M., Peng F. Modeling and Simulation of a Hybrid Energy Storage System for Residential Grid-Tied Solar Microgrid Systems. Journal of Power and Energy Engineering, 2017, vol. 5, no. 5, pp. 28-39. doi: https://doi.org/10.4236/jpee.2017.55003.

14. Barelli L., Bidini G., Bonucci F., Castellini L., Castellini S., Ottaviano A., Pelosi D., Zuccari A. Dynamic Analysis of a Hybrid Energy Storage System (H-ESS) Coupled to a Photovoltaic (PV) Plant. Energies, Feb. 2018, vol. 11, no. 2, p. 396. doi: https://doi.org/10.3390/en11020396.
15. Shavolkin O., Shvedchykova I., Demishonkova S. Simulation model of the photovoltaic system with a storage battery for a local object connected to a grid with multi-zone tariffication. 2020 IEEE 7th International Conference on Energy Smart Systems (ESS), Kyiv, Ukraine, 2020, pp. 368-372. doi: https://doi.org/10.1109/ess50319.2020.9160112.

16. Lawder M.T., Suthar B., Northrop P.W.C., De S., Hoff C.M., Leitermann O., Crow M.L., Santhanagopalan S., Subramanian V.R. Battery Energy Storage System (BESS) and Battery Management System (BMS) for Grid-Scale Applications. Proceedings of the IEEE, Jun. 2014, vol. 102, no. 6, pp. 10141030. doi: https://doi.org/10.1109/jproc.2014.2317451.

17. DG12-100 (12V100Ah). Available at: https://www.ritarpower.com/products/176.html (Accessed 15.08.2020).

18. Photovoltaic geographical information system. Available at: https://re.jrc.ec.europa.eu/pvg_tools/en/tools.html\#SA (Accessed 15.08.2020)

Received 08.11.2020

Accepted 14.02.2021

Published 05.04.2021

A.A. Shavelkin ${ }^{1}$, Doctor of Technical Science, Professor,

J. Gerlici ${ }^{2}$, Professor, Dr. Ing.,

I.O. Shvedchykova ${ }^{1}$, Doctor of Technical Science, Professor,

K. Kravchenko ${ }^{2}, P h D$,

H.V. Kruhliak ${ }^{1}$,

${ }^{1}$ Kyiv National University of Technologies and Design,

2, Nemirovich-Danchenko Str., Kyiv, 01011, Ukraine,

e-mail: ishved89@gmail.com

${ }^{2}$ University of Žilina,

Univerzitná 8215/1, SK 01026 Žilina, Slovak Republic, e-mail: juraj.gerlici@fstroj.uniza.sk

kateryna.kravchenko@fstroj.uniza.sk

How to cite this article:

Shavelkin A.A., Gerlici J., Shvedchykova I.O., Kravchenko K., Kruhliak H.V. Management of power consumption in a photovoltaic system with a storage battery connected to the network with multi-zone electricity pricing to supply the local facility own needs. Electrical Engineering \& Electromechanics, 2021, no. 2, pp. 36-42. doi: 10.20998/2074-272X.2021.2.06. 